\title{
Phytochemical characterization and biological activities of Plectranthus barbatus Andrews
}

\author{
Caracterização fitoquímica e atividades biológicas de Plectranthus barbatus Andrews
}

\author{
M. F. Cordeiro ${ }^{a, b}$ (D), T. R. S. Nunesa (D), F. G. Bezerra ${ }^{a}$ iD, P. K. M. Damascoc (iD, W. A. V. Silva ${ }^{d}$ (D), M. R. A. Ferreirad (iD,

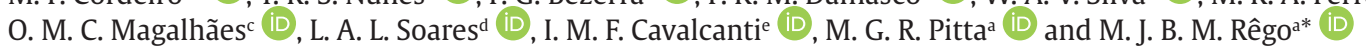 \\ aUniversidade Federal de Pernambuco - UFPE, Research Centre for Therapeutic Innovation - Suely Galdino - NUPIT-SG, Laboratory of \\ Immunomodulation and New Therapeutical Approaches, Recife, PE, Brasil \\ 'Universidade Federal do Vale do São Francisco - UNIVASF, Medicine Collegiate, Paulo Afonso, BA, Brasil \\ cUniversidade Federal de Pernambuco - UFPE, Micology Department, Recife, PE, Brasil \\ dUniversidade Federal de Pernambuco - UFPE, Pharmacy Department, Recife, PE, Brasil \\ eUniversidade Federal de Pernambuco - UFPE, Laboratory of Immunopathology Keizo Asami, Recife, PE, Brasil
}

\begin{abstract}
Plectranthus barbatus Andrews (Lamiaceae) is widely distributed in the world and has a range of popular therapeutic indications. This work aimed to evaluate the phytochemical characterization of two leaf extracts of $P$. barbatus, and their antimicrobial, antineoplastic and immunomodulatory potential. After collection, herborization and obtainment of the P. barbatus aqueous extract (PBA) and acetone:water 7:3 P. barbatus organic extract (PBO), the phytochemical characterization was performed by high-performance liquid chromatography (HPLC). The antimicrobial activity was performed to determine the minimum inhibitory concentration (MIC) against eight bacterial strains using the microdilution test and the fungus Trichophyton rubrum by disc diffusion assay and microdilution test. Cytotoxicity was assessed by MTT and trypan blue methods in normal peripheral blood mononuclear cells (PBMCs) at concentrations ranged between 0.1 to $100 \mu \mathrm{g} \cdot \mathrm{mL}^{-1}$ and in neoplastic cell lines Toledo, K562, DU-145 and PANC-1 at 1, 10 and $100 \mu \mathrm{g} \cdot \mathrm{mL}^{-1}$. Immunomodulatory activity, was evaluated by sandwich ELISA of proinflammatory cytokines at BALB/c mice splenocytes cultures supernatant. Both extracts presented flavonoids, cinnamic derivatives, steroids and ellagic acid. PBO showed bacteriostatic activity against Acinetobacter baumannii $\left(\mathrm{MIC}=250 \mu \mathrm{g} \cdot \mathrm{mL}^{-1}\right)$ clinical isolate and PBA fungistatic activity against Trichophyton rubrum $\left(\mathrm{MIC}=800 \mu \mathrm{g} \cdot \mathrm{mL}^{-1}\right)$. The extracts did not exhibit toxicity to PBMCs and neoplastic cells $\left(\mathrm{IC} 50>100 \mu \mathrm{g} \cdot \mathrm{mL}^{-1}\right.$ ). Additionally, PBO at $100 \mu \mathrm{g}$. $\mathrm{mL}^{-1}$ significantly inhibited IFN $-\gamma$ and IL-17A cytokines $(p=0.03)$. Plectranthus barbatus is a potential candidate for therapeutic use due to its low toxicity in healthy human cells and exhibits biological activities of medical interest as bacteriostatic, fungistatic and immunomodulatory.
\end{abstract}

Keywords: antimicrobial, boldo, cancer, immunomodulation, medicinal plant.

\begin{abstract}
Resumo
Plectranthus barbatus Andrews (Lamiaceae) é amplamente distribuída no mundo e com uma série de indicações terapêuticas populares. Este trabalho teve como objetivo avaliar a caracterização fitoquímica de dois extratos da folha de $P$. barbatus e seu potencial antimicrobiano, antineoplásico e imunomodulador. Após coleta, herborização e obtenção do extrato aquoso (PBA) e acetona: água 7: 3 (orgânico) (PBO) de P. barbatus, a caracterização fitoquímica foi realizada por cromatografia líquida de alta eficiência (CLAE). A atividade antimicrobiana foi realizada para determinar a concentração inibitória mínima (CIM) contra oito cepas bacterianas usando o teste de microdiluição e o fungo Trichophyton rubrum por ensaio de difusão em disco e teste de microdiluição. A citotoxicidade foi avaliada por métodos MTT e azul de tripan em células normais mononucleares do sangue periférico (CMSP) em concentrações variadas entre 0,1 a $100 \mu \mathrm{g} \cdot \mathrm{mL}^{-1}$ e nas linhagens celulares neoplásicas Toledo, K562, DU-145 e PANC-1 em 1, 10 e $100 \mu \mathrm{g} . \mathrm{mL}^{-1}$. A atividade imunomoduladora foi avaliada por ELISA sanduíche de citocinas pró-inflamatórias em sobrenadante de culturas de esplenócitos de camundongos BALB/c. Ambos os extratos apresentaram flavonoides, derivados cinâmicos, esteróides e ácido elágico. O PBO mostrou atividade bacteriostática contra Acinetobacter baumannii ( $\left.\mathrm{CIM}=250 \mu \mathrm{g} \cdot \mathrm{mL}^{-1}\right)$ e atividade fungistática do PBA contra Trichophyton rubrum $\left(\mathrm{CIM}=800 \mu \mathrm{g} \cdot \mathrm{mL}^{-1}\right)$. Os extratos não apresentaram toxicidade para CMSP e células neoplásicas $\left(\mathrm{IC} 50>100 \mu \mathrm{g} \cdot \mathrm{mL}^{-1}\right)$. Além disso, o PBO a $100 \mu \mathrm{g} \cdot \mathrm{mL}^{-1}$ inibiu significativamente as citocinas IFN- $\gamma$ e IL-17A ( $\left.\mathrm{p}=0,03\right)$. Plectranthus barbatus é um candidato potencial para uso terapêutico devido à sua baixa toxicidade em células humanas saudáveis e exibe atividade de interesse médico como bacteriostática, fungistática e imunomoduladora.
\end{abstract}

Palavras-chave: antimicrobiana, boldo, câncer, imunomodulação, planta medicinal. 


\section{Introduction}

In general, several species of plants are used for the treatment and prevention of diseases and are therefore considered as a source of new molecules with diverse biological activities (Cardoso et al., 2014).

Plectranthus barbatus Andrew (Lamiaceae) is generally distributed in Africa, Asia, Australia and South America, more specifically at tropical and subtropical areas of these countries (Lukhoba et al., 2006; Mothana et al., 2014). Plectranthus genus comprehend more than 300 species and $P$. barbatus is one of the major specie commonly used in Brazilian traditional medicine (Alasbahi and Melzig, 2010; Brito et al., 2018). In Brazil it is known as false boldo, Brazilian boldo, boldo do reino, alumã, malva santa, malva amarga, sete dores, boldo do jardim and folha de oxalá (Lorenzi and Matos, 2002).

$P$. barbatus leaves is used in Brazilian traditional medicine in the form of infusion or decoction to treat a variety of diseases including intestinal disorders, heart diseases, liver illness and respiratory disorders. This plant species is also used to relieve inflammatory processes and to treat some nervous system diseases (Lukhoba et al., 2006; Rice et al., 2011).

The main constituent of $P$. barbatus is forskolin, one of more than 67 diterpenoids isolated from the species and whose range of pharmacological properties could explain the different traditional uses of the species. However, this compound has a water-insoluble nature that limits its clinical utility (Alasbahi and Melzig, 2010). Other phytochemicals such as the phenolic derivatives nepetoidins A and B (Grayer et al., 2003) and rosmarinic acid (Falé et al., 2011) were also found in P. barbatus composition (Silva et al., 2016). Phenolic plant-derived compounds comprise the composition of several classes of molecules such as simple phenolics, phenolic acids, coumarins, flavonoids, hydrolysable and condensed tannins, stilbenes, lignans and lignins (Silva et al., 2019) and, some of these have already been identified in P. barbatus extracts (Borges et al., 2020; Ezeonwumelu et al., 2019; Rodrigues et al., 2016).

Given its importance and widespread use in folk medicine, the present study aimed to characterize phytochemically the aqueous and organic extracts of $P$. barbatus and further evaluate their antimicrobial, cytotoxic activity, and immunomodulatory potential.

\section{Material and Methods}

\subsection{Plant material and extracts preparation}

Plectranthus barbatus Andrew (Lamiaceae) was collected at the Centro de Treinamento do Instituto de Pesquisa Agropecuária (CETREINO/IPA), located in Carpina, Pernambuco, Brazil ( $07^{\circ} 51^{\prime} 03^{\prime \prime}$ S 35 $\left.15^{\prime} 17^{\prime \prime} \mathrm{W}\right)$, under controlled growing conditions. After collection, a voucher specimen was identified by Dra. Rita de Cássia Pereira and deposited at the IPA Herbarium (\#91410).

Subsequently, the leaves were dried in circulating air oven $\left(82 / 480\right.$, Lucadema $\left.{ }^{\circledR}\right)$ at $40^{\circ} \mathrm{C}$ during 48 hours and the dried material was pulverized in Willye-type knife mill (TE-680, Tecnal ${ }^{\circledR}$ ). The extracts were obtained by $10 \%(\mathrm{w} / \mathrm{v})$ turboextraction (Metvisa ${ }^{\circledR}$ ) using water or the acetone: water mixture $(7: 3, v / v)$. The acetone: water extract, after filtration, was concentrated under reduced pressure (RV10 Basic, IKA ${ }^{\circledR}$ ). Then, the remained extracts were frozen $\left(-80{ }^{\circ} \mathrm{C}\right.$, for 3 days $)$ and lyophilized (at $-45^{\circ} \mathrm{C}$; L101, Liotop ${ }^{\circledR}$ ), yielding the $P$. barbatus aqueous extract (PBA) and the P. barbatus organic extract (PBO).

\subsection{Thin Layer Chromatography (TLC)}

A final concentration of $1 \mathrm{mg} \cdot \mathrm{mL}^{-1}$ was obtained dissolving the extracts in methanol and vortex for complete dissolution. The samples and standards ( $1 \mathrm{mg} \cdot \mathrm{mL}^{-1}$ ) were applied, 20 and $5 \mu$, respectively, on silica gel 60 - F254 (Macherey-Nagel@) chromatographic plates, with a semi-automatic applicator (Camag®) and software (WinCats ${ }^{\circledR}$ ). After saturation with the mobile phase (Supplementary Material - Table S1) for about 30 minutes at room temperature $\left(25 \pm 2{ }^{\circ} \mathrm{C}\right)$ the chromatographic plates were developed in a twin trough glass chamber (20 cm x $10 \mathrm{~cm}$, Camag®).

After elution, the plates were dried at room temperature and observed under ultraviolet light of 254 and $365 \mathrm{~nm}$ and visible light. Then, the plates were derivatized with specific reagents for each metabolite (Supplementary Material - Table S1) and the bands visualized on the samples were compared to the corresponding standards.

\subsection{High Performance Liquid Chromatography (HPLC)}

Twenty-five mg of PBA and PBO were transferred to a $25 \mathrm{~mL}$ volumetric flask and added $15 \mathrm{~mL}$ of ultrapure water. The samples were taken to the ultrasonic bath (Ultracleaner, Unique $^{\circledR}$ ) for 15 minutes for complete dissolution. The obtained solution was filtered through $0.45 \mu \mathrm{m}$ syringe filters (CHROMAFIL PVDF, MachereyNage $\left.{ }^{\circledR}\right)$ to vials. The caffeic acid and rutin standards (Sigma-Aldrich ${ }^{\circledR}$ ) were prepared in ethanol: water $(50 \%, v / v)$ (HPLC grade, Tedia $\left.{ }^{\circledR}\right)$, filtered and analysed. The analysis was conducted in a chromatograph (Ultimate 3000 , ThermoScientific ${ }^{\circledR}$ ) equipped with photodiode array detector. A pre-column (3.9 mm) (Phenomenex $\left.{ }^{\circledR}\right), 250 \mathrm{~mm}$ long and $4.6 \mathrm{~mm}$ internal diameter column $\left(\mathrm{NST}^{\circledR}\right)$, packed with silica chemically attached to the octadecylsilane group $(5 \mu \mathrm{m})$, maintained at $24{ }^{\circ} \mathrm{C}$. The mobile phase consisted of water (trifluoracetic acid 0.05\%) as solvent $A$ and methanol (trifluoracetic acid $0.05 \%$ ) as solvent $\mathrm{B}$, with flow maintained at $0.8 \mathrm{~mL} /$ minute. Both were degassed in an ultrasonic bath and filtered through a $0.45 \mu \mathrm{m}$ pore membrane. The injection volume used was $20 \mu \mathrm{L}$. The wavelength of the analyzes was set at $280 \mathrm{~nm}$ after scanning. The separation was conducted using the following linear gradient: $0-10 \mathrm{~min}, 10-25 \% \mathrm{~B}$; 10-20 min, 25-40\% B; 20-25 min, 40-75\% B; 25-28 min, 75-10\% B; $28-30 \mathrm{~min}, 75-10 \% \mathrm{~B}$. All assays were done in triplicate. 


\subsection{Antibacterial activity}

Clinical isolates of Acinetobacter baumannii, Klebsiella pneumoniae, extended-spectrum beta-lactamase (ESBL), and carbapenemase-producing Klebsiella pneumoniae (KPC) were obtained from the Hospital das Clínicas of the Federal University of Pernambuco and kept at the Laboratory of Immunopathology Keizo Asami (LIKA / UFPE). These clinical isolates were phenotypically identified according to the guidelines of the Clinical and Laboratory Standard Institute (CLSI, 2016). Reference strains were obtained from the American Type Culture Collection (ATCC), such as methicillin-resistant Staphylococcus aureus (MRSA) ATCC 33591, methicillin-sensitive Staphylococcus aureus (MSSA) ATCC 29213, Escherichia coli ATCC 25922, Klebsiella pneumoniae ATCC 29665 and Pseudomonas aeruginosa ATCC 27853.

The antibacterial activity of $P$. barbatus extracts was evaluated by the microdilution method according to the CLSI guidelines. Initially, the 96-well microdilution plates were filled with Müller-Hinton broth (MHB). Then the extracts previously diluted in $0.5 \%$ dimethylsulfoxide (DMSO) were distributed through serial dilution in order to obtain concentrations ranging from 1 to $500 \mu \mathrm{g} \cdot \mathrm{mL}^{-1}$. As reference drugs Vancomycin and Ciprofloxacin, at 0.0075 to $3.84 \mu \mathrm{g} \cdot \mathrm{mL}^{-1}$, were used for Gram-positive and Gram-negative bacteria.

The bacterial suspensions were further adjusted to 0.5 of the McFarland scale and diluted to obtain $10^{5} \mathrm{CFU} / \mathrm{mL}$ in each well. The microplates were incubated at $35 \pm 2{ }^{\circ} \mathrm{C}$ for 24 hours and the minimum inhibitory concentration (MIC) was determined using $20 \mu \mathrm{L}$ resazurin (Sigma).

Briefly, minimum bactericidal concentration (MBC) was determined on plates containing Müller-Hinton agar (MHA) and considered as the lowest concentration of extracts associated with absence of bacterial growth. Tests were done in triplicate.

\subsection{Antifungal activity}

Three cultures of Trichophyton rubrum preserved under mineral oil (Sherf, 1943) were used in duplicate, maintained and supplied by the Collection of Cultures - Micoteca URM, Department of Mycology, Center of Biosciences, Federal University of Pernambuco. The preserved cultures were reactivated, transferring a culture fragment to glycosated broth and then replaced to Sabouraud agar, maintained at room temperature $\left(\mathrm{RT}=30^{\circ} \mathrm{C} \pm 2^{\circ} \mathrm{C}\right)$.

The antifungal activity of the extracts against T. rubrum cultures was evaluated by means of the disc diffusion test according to the methodology modified by Ichikawa et al. (1971). Cultures with 10 days of growth in Sabouraud Agar (g.L-1: dextrose 40 , peptone 10 and agar 18 ) were incubated at $25^{\circ} \mathrm{C}$ in test tubes and suspensions were prepared in sterilized distilled water with tween and adjusted, for spectrophotometer, to obtain a transmittance of $78-80 \%$. Subsequently, $2 \mathrm{~mL}$ of the standard suspension were added to previously sterilized Petri dishes, $15 \mathrm{~mL}$ of the Sabouraud agar medium being added at a temperature of approximately $45^{\circ} \mathrm{C}$. After solidification, a sterile $5 \mathrm{~mm}$ diameter disc was placed and moistened with extracts containing $0.0016 \mathrm{mg}$ dissolved in $1 \mathrm{~mL}$ DMSO. Plates were maintained at $28^{\circ} \mathrm{C} \pm 2^{\circ} \mathrm{C}$ for 48 hours. After incubation, the presence or absence of halos was verified. The inhibition halos were measured in millimeters and expressed as arithmetic mean. As a control to check the solvent effect, a disk with DMSO was inoculated under the same conditions.

This method followed the conditions described by Clinical and Laboratory Standard Institute (CLSI, 2008). Fungus isolates were peeled in potato Dextrose Agar (BDA) medium in test tubes and incubated for six to seven days at $30^{\circ} \mathrm{C}$ until sufficient conidia were present. Sequentially, $3 \mathrm{~mL}$ of $0.85 \%$ sterile saline solution added with tween 20 was added to the fungal colonies. The suspension was homogenized with a pipette and subsequently the resulting mixture was transferred to sterile test tubes. After five minutes of standing, the supernatant was transferred to another sterilized test tube and shaken for 15 seconds in vortex. The density of the suspension was adjusted in the spectrophotometer to obtain transmittance of $65-70 \%$ at wavelength $530 \mathrm{~nm}$. The suspensions were then diluted (1:50) in RPMI 1640 to give a final concentration of $0.4 \times 10^{4}$ to $5 \times 10^{4} \mathrm{CFU} / \mathrm{mL}$.

In 96-well flat-bottomed microtiter plates, $100 \mu \mathrm{L}$ of RPMI 1640 culture medium was distributed in all wells. At the following dilution, $100 \mu \mathrm{L}$ of the extract, at a concentration of 1600 to $3.125 \mu \mathrm{g} \cdot \mathrm{mL}^{-1}$, was used as growth and sterilization control, respectively. Subsequently, $100 \mu \mathrm{L}$ of the standardized inoculum was added to the wells of columns 1 to 11 , and the microplate was incubated for 48 hours at $35^{\circ} \mathrm{C}$. Minimum inhibitory concentration (MIC) was defined as the lowest concentration of antifungal capable of inhibiting 50\% to $90 \%$ growth.

\subsection{Antineoplastic activity}

Cytotoxicity was evaluated initially against normal cells as described by Rêgo et al. (2014). The trials were only started after approval by the Ethics Committee on Research Involving Human Beings of the Health Science Center of UFPE, under the CAAE: 46976315.9.0000.5208. All volunteers gave their informed consent.

Four clinically healthy individuals were included in the selection. Peripheral blood mononuclear cells (PBMCs) contained in blood collected in heparin tubes as anticoagulants were isolated by centrifugation with Ficoll Paque TM Plus (GE Healthcare Bio-Sciences). After, they were cultured in RPMI 1640 medium (Gibco) supplemented with L-Glutamine, 10\% Fetal Bovine Serum (Lonza), 10 mM HEPES (Gibco) and 200 (4- (2-hydroxyethyl) -1-piperazineethanesulfonic acid) U/mL Penicillin/ Streptomycin (Gibco). PBMCs were used only when they showed viability equal to or greater than $98 \%$ after counting in Neubauer chamber with trypan blue.

The PBMCs were grown at $5 \% \mathrm{CO}_{2}$ and $37^{\circ} \mathrm{C}$ atmosphere in the amount of $5.5 \times 10^{5}$ cells/well in quadruplicate for $48 \mathrm{~h}$. After that time, MTT $\left(20 \mu \mathrm{g} \cdot \mathrm{mL}^{-1}\right)$ was added for $3 \mathrm{~h}$ in the oven and, finally, 20\% sodium Dodecyl sulfate (SDS) for dissolution of the crystals. After $24 \mathrm{~h}$, the plates were read in Spectrophotometer at $570 \mathrm{~nm}$. The extracts were tested at 0.1 to $100 \mu \mathrm{g} \cdot \mathrm{mL}^{-1}$. To evaluate the cytotoxicity 
by trypan blue assay, after incubation for 48 hours of PBA and PBO extracts at 1,10 and $100 \mu \mathrm{g} \cdot \mathrm{mL}^{-1}$, a $20 \mu \mathrm{L}$ aliquot of the cell suspension was diluted in $20 \mu \mathrm{L}$ of trypan blue. The cells were observed for their morphological changes and counted in Neubauer's chamber. After counting, the following mathematical formula 1 was applied, which gives the result of the cytotoxicity of the extracts against the PBMCs from the cellular viability values of each condition:

$$
\mathrm{V}(\%)=(\# \text { live cells } / \# \text { lives }+ \text { dead cells }) \times 100
$$

As a negative control, the condition with only cell was used for the extracts diluted in water (PBA), and the condition of cell with $0.1 \%$ DMSO for the extracts diluted in DMSO (PBO).

The same methodologies were performed for the cytotoxicity assay in neoplastic cells: TOLEDO (NonHodgkin B Cell Lymphoma), K562 (Chronic Myeloid Leukemia), DU-145 (Prostate Cancer) and PANC-1 (Pancreatic Cancer) at 1, 10 and $100 \mu \mathrm{g} \cdot \mathrm{mL}^{-1}$ of PBA and PBO.

\subsection{Immunomodulatory potential}

To evaluate the cytokine modulation, we conducted the methodology described by Carvalho et al. (2016). Six male BALB/c mice with 45 days of life were sacrificed in a $\mathrm{CO}_{2}$ chamber, according to the Guidelines of the Ethics Committee for the Use of Experimental Animals of the UFPE (Process no 23076.041556/2015-62).

Briefly, the spleens were aseptically extracted and placed in a Petri dish containing RPMI-1640 (Gibco) to obtain splenocytes. The obtained cell suspension was filtered on $40 \mu$ m nylon (BD Falcon ${ }^{\mathrm{TM}}$ ) and transferred to Falcon tubes. Spleen concentrates were washed and lysed with $1 \mathrm{x}$ RBC lysis buffer (eBiosciences) and subsequently resuspended in RPMI-1640 medium (Sigma) supplemented with $10 \%$ fetal bovine serum, 10 mM HEPES (4- (2-hydroxyethyl) -1-piperazinoethanesulfonic acid) (Gibco) and $200 \mathrm{U} / \mathrm{mL}$ penicillin/streptomycin (Gibco). The evaluation of PBA and PBO cytotoxicity was performed by incubation (10 and $100 \mu \mathrm{g} . \mathrm{mL}^{-1}$ ) for $48 \mathrm{~h}$ at $5 \% \mathrm{CO} 2$ and $37^{\circ} \mathrm{C}$. After $48 \mathrm{~h}$, MTT was added as described in item 2.5 .

Splenocytes were then cultured in 24 well plates ( $2 \times 10^{6} / \mathrm{mL}$ in each well) in RPMI-1640 medium (Gibco) supplemented with $10 \%$ fetal bovine serum (Gibco), $10 \mathrm{mM}$ HEPES (Gibco) and penicillin and $200 \mathrm{U}$ streptomycin $/ \mathrm{mL}$ (Gibco). As a stimulus, was used Concanavalin A (ConA) at 100 ng. $\mathrm{mL}^{-1}$. As the reference drug, methylprednisolone was added at $100 \mu \mathrm{M}$. The PBA and PBO extracts were introduced at 10 and $100 \mu \mathrm{g} \cdot \mathrm{mL}^{-1}$ and incubated at $37^{\circ} \mathrm{C}$ and $5 \% \mathrm{CO}_{2}$ for $48 \mathrm{~h}$.

After incubation, $1 \mathrm{~mL}$ of culture supernatant was collected from each well, stored at $-30^{\circ} \mathrm{C}$ until use. Cytokine determination was performed by sandwich ELISA (mouse), following the manufacturer's information. The minimum detection limits for IFN- $\gamma$ and IL-17A analysis was $15.62 \mathrm{pg} \cdot \mathrm{mL}^{-1}$.

\subsection{Statistics}

To assess the normal distribution of variables, the Kolmogorov-Smirnov test was used. The variables that did not present normal distribution were analyzed through the Wilcoxon non-parametric test and presented as maximum and minimum median. Analyzes were performed using GraphPad Prism ${ }^{\circledR}$ software version 6 and considered significant values when $\mathrm{p}<0.05$.

\section{Results}

According to the analysis by TLC, spots of yellow and orange color indicating the presence of flavonoids and bluegreen indicating the presence of cinnamic derivatives (A); no condensed tannins (B) and hydrolysable tannins (C) were found in any of the extracts; finally, bands of blue color were observed in the plate obtained for terpenes/ steroids (D), indicating the presence of compounds of the class (Figure S1).

The chromatograms from HPLC analysis of PBA and PBO extracts can be visualized in Figure 1. In both chromatographic profiles, the presence of cinnamic derivatives was detected, with a retention time (tR) of 19.83 (peak 1, corresponding to the presence of caffeic acid) and $25.5 \mathrm{~min}$ (peak 2) approximately in both extracts PBA and PBO. In addition, the others peaks (3-6) have characteristic of the flavonoids metabolites observed in both extracts, but with greater area value evidenced in the PBO extract, with tR at 26.25, 26.55, 26.92, 27.29 and $27.41 \mathrm{~min}$. Caffeic acid and rutin standards were injected, and the presence of caffeic acid in the samples was confirmed by the same retention time and scanning spectrum of the obtained peaks. In addition, although no peak corresponds to the rutin (flavonoid), the spectra of peaks 3 to 7 show a characteristic of the flavonoid class with three absorption maxima.

PBA did not show antibacterial activity against clinical isolates. PBO, in turn, had a bacteriostatic effect against all eight isolates tested, including strains with resistance profile $\left(\mathrm{MIC}=500 \mu \mathrm{g} \cdot \mathrm{mL}^{-1}\right)$ as ESBL, KPC and MRSA. In addition, PBO had bacteriostatic activity against the Acinetobacter baumannii clinical isolate $\left(\mathrm{MIC}=250 \mu \mathrm{g} \cdot \mathrm{mL}^{-1}\right)$ as shown in Table 1.

After analysis of disc-diffusion assay were identified a halo inhibition about $6 \mathrm{~mm}$ with PBA treatment. However, the halo inhibition activity of PBO was not evidenced. Due to Trichophyton rubrum growth inhibition by PBA we conducted the microdilution test and it was evidenced that PBA shows fungistatic activity ( $\left.\mathrm{MIC}=800 \mu \mathrm{g} \cdot \mathrm{mL}^{-1}\right)$ against this microorganism.

The results of MTT and trypan blue viability tests showed that PBA (see Figures 2A and 2B) and PBO (see Figures $2 \mathrm{C}$ and 2D) did not exhibit cytotoxicity against PBMCs. However, for neoplastic lineages, PBA and PBO exhibited different cytotoxicity depending on the tested concentration. PBO at $100 \mu \mathrm{g} \cdot \mathrm{mL}^{-1}$ appear to be more cytotoxic for all neoplastic tested lineages. Despite this we did not found IC50 values to no one evaluated neoplastic cells (Figure 3).

Regarding the evaluation of extracts in reduction of cytokine levels, PBA [188.63 pg.mL-1 (70.79 pg.mL ${ }^{-1}$ - 610.37 pg.mL-1)] did not inhibit IL-17A cytokine production at tested concentrations when compared to 

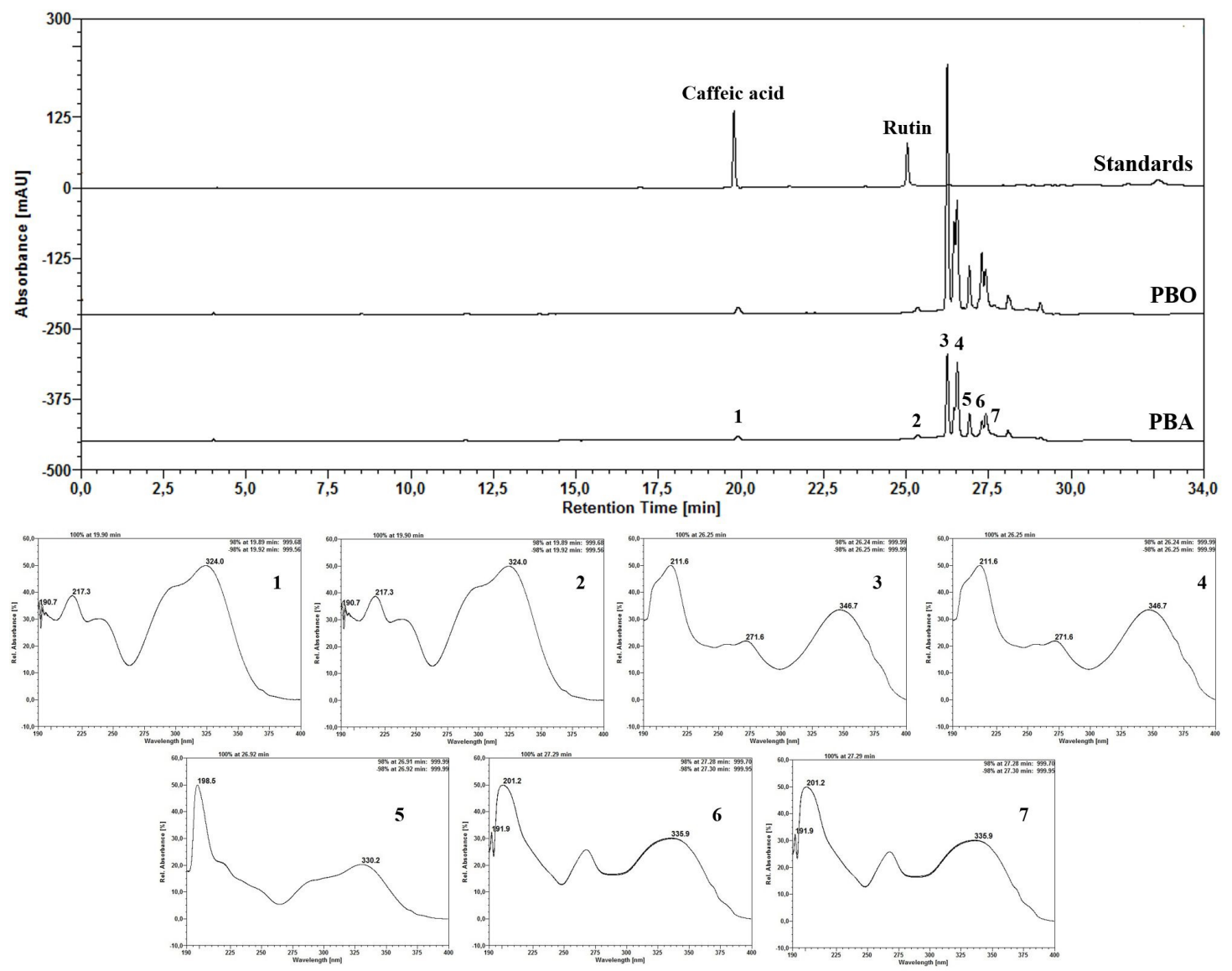

Figure 1. Chromatograms of Plectranthus barbatus aqueous extract (PBA) and acetone: water (PBO). Detection at $280 \mathrm{~nm}$.

Table 1. Antibacterial activity of aqueous extracts (PBA) and acetone: water (PBO) of Plectranthus barbatus against pathogenic bacteria.

\begin{tabular}{|c|c|c|}
\hline \multirow{2}{*}{ Bacterial Strains } & PBA & PBO \\
\hline & \multicolumn{2}{|c|}{ MIC ( $\mu$ g.mL $\left.\mathbf{m}^{-1}\right)$} \\
\hline MSSA ATCC 29213 & $>500$ & 500 \\
\hline MRSA ATCC 33591 & $>500$ & 500 \\
\hline Escherichia coli ATCC 25922 & $>500$ & 500 \\
\hline Klebsiella pneumoniae ATCC 29665 & $>500$ & 500 \\
\hline Pseudomonas aeruginosa ATCC 27853 & $>500$ & 500 \\
\hline Acinetobacter baumannii clinical isolate & $>500$ & 250 \\
\hline ESBL clinical isolate & $>500$ & 500 \\
\hline KPC clinical isolate & $>500$ & 500 \\
\hline
\end{tabular}

MIC: Minimum Inhibitory Concentration; MSSA: Methicillin-sensitive Staphylococcus aureus; MRSA: Methicillin-resistant Staphylococcus aureus; ESBL: Klebsiella pneumoniae producing extended-spectrum beta-lactamase; KPC: Klebsiella pneumoniae producing carbapenemase.

ConA (stimulated control) [128.63 pg.mL $\mathrm{mL}^{-1}\left(55.79 \mathrm{pg} \cdot \mathrm{mL}^{-1}\right.$ - 387.76 pg.mL $\left.\mathrm{mL}^{-1}\right)$. However, the greater result was found after PBO treatment, decreasing IL-17A levels, notably at $100 \mu$ g.mL $L^{-1}\left(15.62\right.$ pg.mL ${ }^{-1}\left(15.62\right.$ pg.mL ${ }^{-1}-45.79$ pg.mL $\left.{ }^{-1}\right)$ ) (see Figure 4A) $(\mathrm{p}=0.03)$.

Additionally, the treatment with $\mathrm{PBO}$ in relation to ConA [13554.1 pg.mL $\mathrm{m}^{-1}$ (2342.96 pg.mL $\left.\mathrm{m}^{-1}-35280.12 \mathrm{pg} \cdot \mathrm{mL}^{-1}\right)$ ], significative decreased IFN- $\gamma$ levels at all evaluated concentrations as we describe below. PBA $10 \mu \mathrm{g} \cdot \mathrm{mL}^{-1}$ was not significant but PBA $100 \mu \mathrm{g} \cdot \mathrm{mL}^{-1}$ [5765.64 pg.mL $\mathrm{mL}^{-1}\left(62.5 \mathrm{pg} \cdot \mathrm{mL}^{-1}\right.$ - 12846.41 pg.mL $\left.L^{-1}\right)$ ], PBO $10 \mu \mathrm{g} \cdot \mathrm{mL}^{-1}$ [2023.33 pg.mL ${ }^{-1}$ (62.5 pg.mL $\mathrm{mL}^{-1}-8577.18$ pg.mL $\mathrm{mL}^{-1}$ )] and PBO $100 \mu \mathrm{g} \cdot \mathrm{mL}^{-1}$ [39.06 pg.mL $\mathrm{mL}^{-1}\left(15.62\right.$ pg.mL $\mathrm{L}^{-1}-1884.87$ pg.mL $\left.\mathrm{mL}^{-1}\right)$ ] showed significant values $(\mathrm{p}=0.03$ ) (see Figure $4 \mathrm{~B}$ ).

\section{Discussion}

P. barbatus, especially from India, Brazil, Kenya and China has been an attractive plant for development of chemical and pharmacological studies to discovery novel biologically active constituents. P. barbatus main constituents isolated from different parts of this species are diterpenoids, and these phytochemicals are responsible for many described biological activities (Alasbahi and Melzig, 2010). However, the presence of phenolic compounds in $P$. barbatus extracts has been reported in several studies (Brito et al., 2018, Ganash \& Qanash, 2018, Shaheen et al., 2017, Silva et al., 2016, Rodrigues et al., 2016). Thus, in order to elucidate the biological activities of $P$. barbatus leaves extracts that contains phenolic compounds, here we conducted the evaluation of 
A)

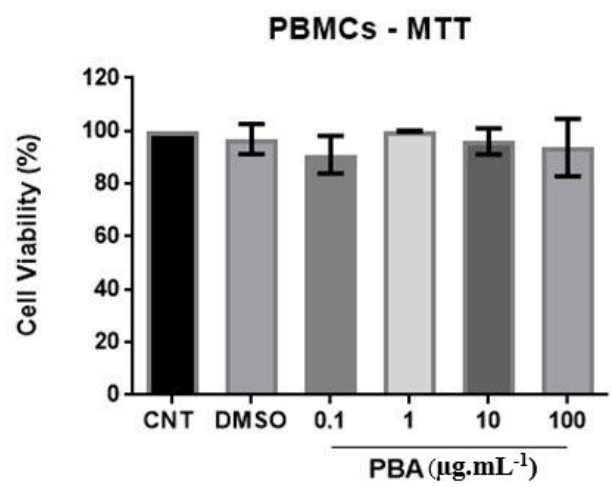

C)

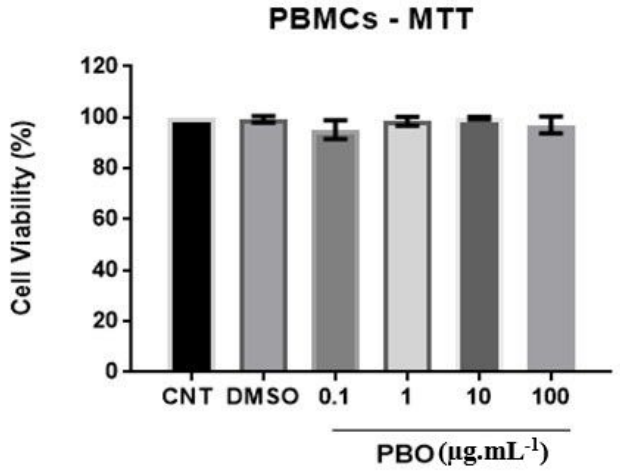

B)

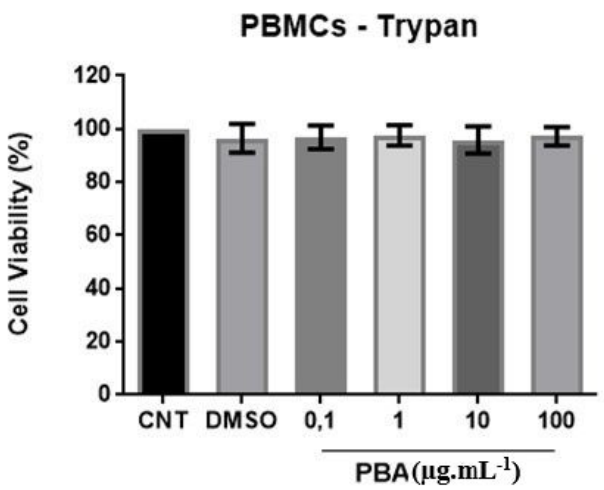

D)

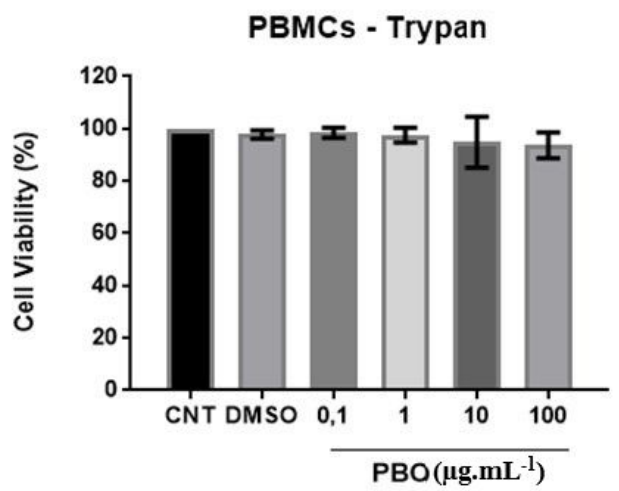

Figure 2. Evaluation of cytotoxic activity of Plectranthus barbatus extracts against untransformed human cells in A (MTT) and B (Trypan Blue) are shown aqueous extract - PBA profile; C (MTT) and D (Trypan Blue) are present acetone: water - PBO profile at four different concentrations $\left(0.1,1,10\right.$, and $\left.100 \mu \mathrm{g} \cdot \mathrm{mL}^{-1}\right)$. CNT: Untreated control.

antimicrobial, antineoplastic and immunomodulatory potential of these extracts.

The phytochemical characterization of our extracts indicated the presence of flavonoids, cinnamic derivatives, steroids and ellagic acid in both extracts. Caffeic acid was evidenced in both extracts, however rosmarinic acid is the major evidenced compound in $P$. barbatus extracts (Brito et al., 2018). Rosmarinic acid is an ester of caffeic acid and 3,4dihydroxyphenyllactic acid and it is known that this compound presents several biological activities such as antimicrobial, anti-inflammatory, antioxidant, anti-viral and adstringent. As presented in literature, the rosmarinic acid is formed by tow molecules of caffeic acid, joined by an ester bond (Gamaro et al., 2011). Both molecules belong to the same class of compounds, the phenylpropanoids, therefore it can be related to the biological activities here observed. In addition, the differences of chemical contents in our extracts and the related literature about extracts of $P$. barbatus leaves is probably be associated with the phenological cycle, where the temperature, light and humidity environmental when the plant was collected can influence the amount of the different substances found on herbal material (Raudone et al., 2017).

Then we evaluated the antibacterial activity and observed that the organic extract PBO presented bacteriostatic activity against all bacterial isolates, especially against Acinetobacter baumannii. A study conducted by Rodrigues et al. (2016) identified the antibacterial activity in extract of the aerial parts of $P$. barbatus against $S$. aureus however they evaluated this activity through the growth inhibition zone and the extract showed $9.03 \pm 0.103 \mathrm{~mm}$ of inhibition. In addition, these authors correlated this observation with the presence of phenolic compounds in the extract of $P$. barbatus once that the probable mechanism of action of phenolic compounds is related on bacterial cytoplasmic membrane. These molecules alter the structure and function of cytoplasmic membrane coagulating the cell content and interfering with active transport (Almeida, 2007). Ahmad et al. (2015) also explain that the phenolic compounds can acts interacting with proteins, generating redox imbalance and acting on the cell wall.

In addition, Acinetobacter baumannii is gram-negative bacteria that is related with several nosocomial infections. Other microorganisms, as E. coli and S. aureus that causes these infections were objects of study regarding the discovery of new therapeutic options. Matu and Van Staden (2003) used the aqueous, hexanic and methanolic extracts of $P$. barbatus leaves to identify their actions against gram-positive bacteria (Bacillus subtilis, Micrococcus luteus, Staphylococcus aureus) and gram-negative (E. coli and K. pneumoniae) bacteria. At their study it was identified 
A)

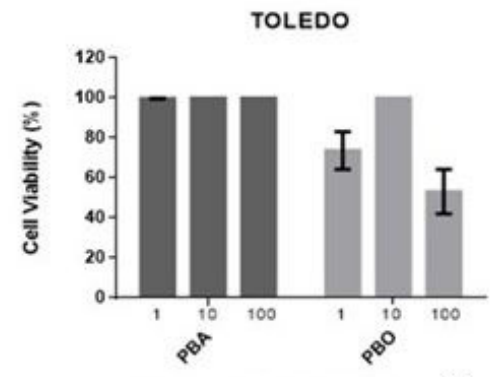

Compound Concentration $\mu \mathrm{g} \cdot \mathrm{mL}^{-1}$

C)

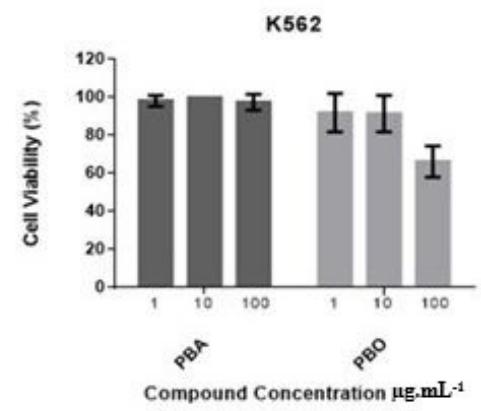

E)

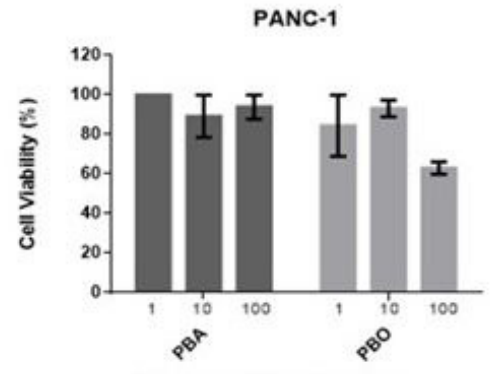

G)

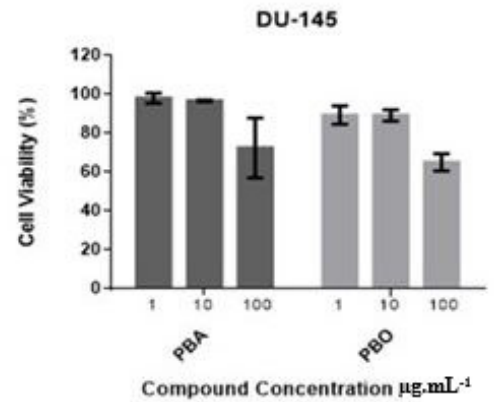

B)

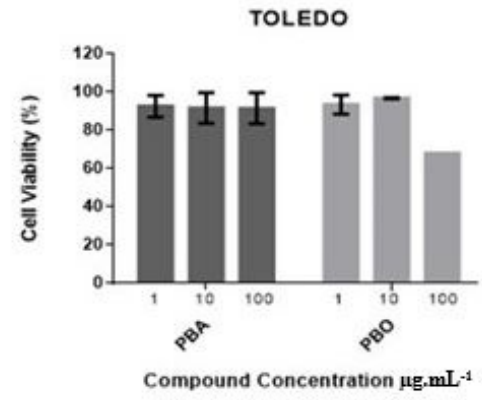

D)

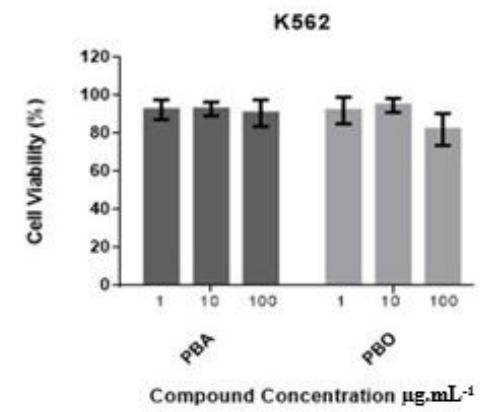

F)

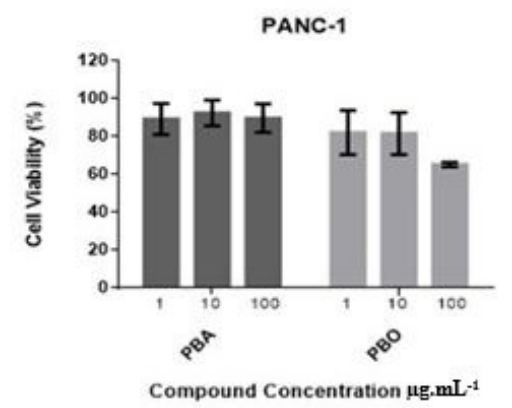

H)

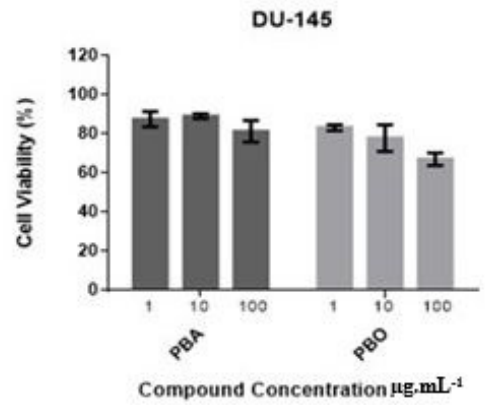

Figure 3. Plectranthus barbatus extracts influence against neoplastic cells lineages. TOLEDO, K562, DU-145 and PANC-1 neoplastic cell lines at 1,10 and $100 \mu \mathrm{g} \cdot \mathrm{mL}^{-1}$ of PBA and PBO with MTT (A, C, E, G) and Trypan Blue (B, D, F, H) assays. 
A)

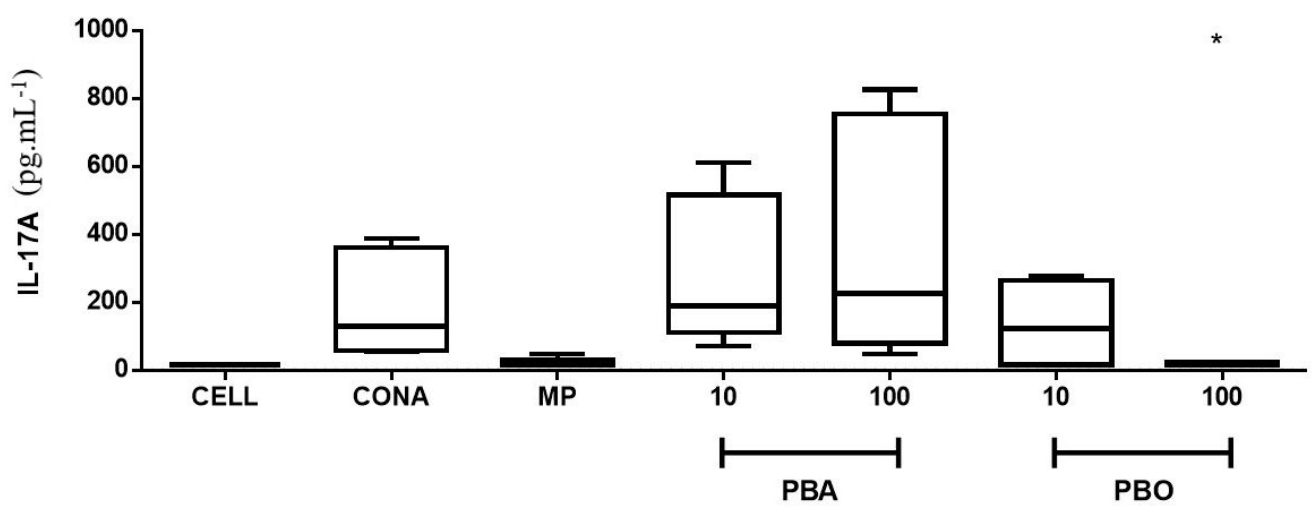

B)

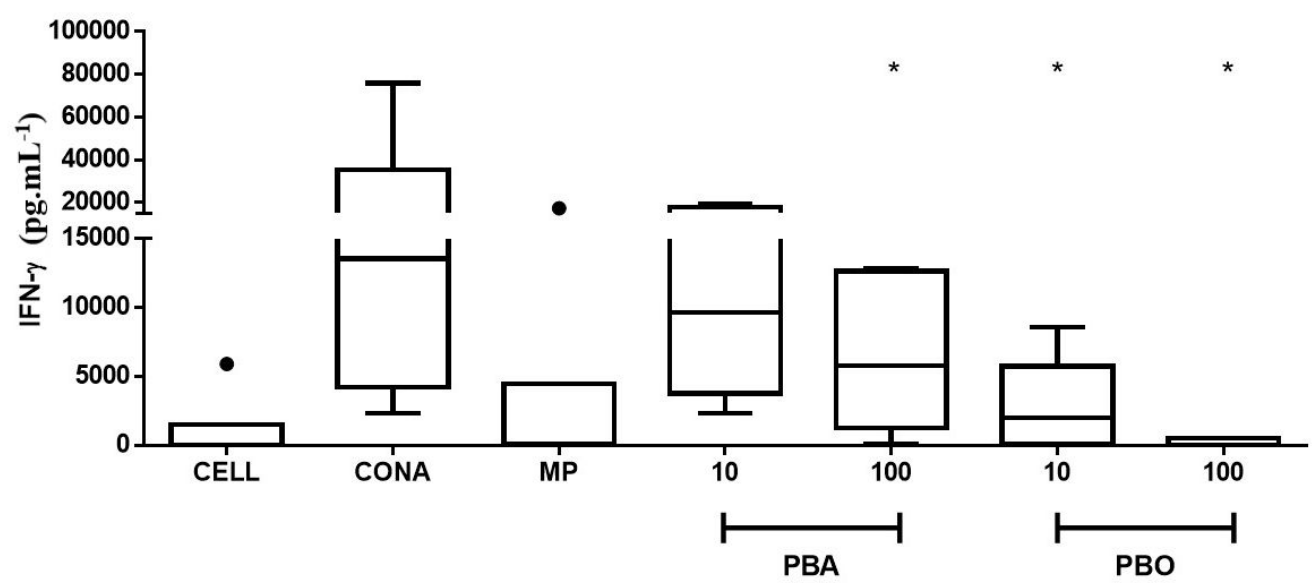

Figure 4. Cytokine titration in culture supernatant of BALB/c splenocytes treated with Plectranthus barbatus (aqueous: PBA; acetone: water: PBO) extracts at 10 and $100 \mu \mathrm{g} \cdot \mathrm{mL}^{-1}$. (A) levels of IL-17A; (B) IFN- $\gamma$ levels. CELL = untreated control; CONA = Concanavalin A; $\mathrm{MP}=$ methylprednisolone at $100 \mu \mathrm{M} ;\left(^{*}\right) \mathrm{p}=0.03 ;(\bullet)$ represents outliers.

that the methanolic extract showed activity against all Gram-positive isolates. However, Santos Veríssimo et al. (2014) identified the antibacterial activity of the crude ethanol extract of $P$. barbatus leaves against $E$. coli showing a MIC $=6250 \mu \mathrm{g} \cdot \mathrm{mL}^{-1}$ and also against Staphylococcus aureus (MIC $=3120 \mu \mathrm{g} \cdot \mathrm{mL}^{-1}$ ). Araújo et al. (2014) also evaluated the antibacterial action of the leaf extract of $P$. barbatus, which presented bacteriostatic activity against E. coli $\left(\mathrm{MIC}=250 \mu \mathrm{g} \cdot \mathrm{mL}-1, \mathrm{MBC}>2000 \mu \mathrm{g} \cdot \mathrm{mL}^{-1}\right)$ and $P$. aeruginosa $\left(\mathrm{MIC}=250 \mu \mathrm{g} \cdot \mathrm{mL}^{-1}, \mathrm{MBC}=2000 \mu \mathrm{g} \cdot \mathrm{mL}^{-1}\right)$. Our data corroborate with these authors regarding the greater activity of the organic extract compared to the aqueous one in relation to pathogenic bacteria.

Regarding the activity of extract against multidrugresistant strains, Assis et al. (2018) evaluated the ethanol extract of three Lamiaceae species against Acinetobacter baumannii, Klebsiella pneumoniae, Escherichia coli and Pseudomonas aeruginosa clinical isolates with multidrugresistant profile. They identified that the $P$. barbatus extract was the most effectiveness, exhibiting MIC of 2000, 1000, 1000 and $500 \mu \mathrm{g} \cdot \mathrm{mL}^{-1}$ respectively, however, they did not identify the extract composition. Furthermore, our extract that presents phenolic compounds showed bacteriostatic activity against KPC, ESBL and MRSA, and some studies indicate that these molecules showed activity against multidrug-resistant strains (Kępa et al., 2018; Aldulaimi, 2017; Luís et al., 2013). Thus, phenolic compounds are considered promising weapons in the arsenal of natural antimicrobials acting against a wide spectrum of microorganisms, including multidrug-resistant bacteria, that cause nosocomial infections (MiklasínskaMajdanik et al., 2018).

Though PBA did not exhibit bacteriostatic activity, this extract was fungistatic against Trichophyton rubrum. The study about antifungal activity of $P$. barbatus is scarce, however Runyoro et al. (2006) studied the root extract of this plant against Candida albicans and it was effective on in vitro treatment of this microorganism. Araújo et al. (2019) identified the antifungal activity of ethanol extract of $P$. barbatus leaves against species involved in invasive fungal disease and showed the greatest MIC values against Candida glabrata $\left(31.2 \mu \mathrm{g} \cdot \mathrm{mL}^{-1}\right)$, Saccharomyces cerevisiae, Rhodotorula mucilaginosa, Candida krusei, Candida parapsilosis and Candida gattii (all with MIC $=62.5 \mu \mathrm{g} \cdot \mathrm{mL}^{-1}$ ), 
associating these findings with the presence of steroids/ triterpenes, flavonoids, and alkaloid.

The tested extracts in our study showed no toxicity to PBMCs. We observed that the toxicity of the organic extract at $100 \mu \mathrm{g} \cdot \mathrm{mL}^{-1}$ was highlighted in the four neoplastic cell lines but did not present IC50 values lower than $100 \mu \mathrm{g} \cdot \mathrm{mL}^{-1}$. Saeed et al. (2016) evaluated the cytotoxicity of the methanolic extract of $P$. barbatus leaves against two neoplastic leukemia lines, CCRF-CEM, as sensitive lineage and a multiresistant drug cell line (CEM / ADR5000), through resazurin assay. The tested concentration of the extract ( $\left.10 \mu \mathrm{g} \cdot \mathrm{mL}^{-1}\right)$ presented cytotoxic activity against the two cells lines, with IC50 $=5.7 \pm 1.29 \mu \mathrm{g} \cdot \mathrm{mL}^{-1}$ (CCRFCEM) and IC50 = $7.93 \pm 0.64 \mu \mathrm{g} \cdot \mathrm{mL}^{-1}$ (CEM / ADR5000). Although they correlated these results to the presence of forskolin and coleusin factor, they did not isolate them, but mentioned that these molecules showed cytotoxicity to murine melanoma cells (Agarwal and Parks Junior, 1983) and osteosarcoma (Geng et al., 2014). In addition, Borges et al. (2020) identified an antineoplastic activity (IC50 $\left.=33.89 \pm 0.32 \mu \mathrm{g} \cdot \mathrm{mL}^{-1}\right)$ of ethyl acetate fraction (EAF) of $P$. barbatus leaves, but the identified constituents of EAF were plectrin, hydrolyzed abieatane, barbatusin, $3 \beta$-hydroxy-3-deoxibarbatusin, cyclobutatusin, luteolin, rosmarinic acid and coleoside $\mathrm{B}$ which we did not detect in our extracts.

Regarding the action of caffeic acid, although there are several studies with the antineoplastic activity of this substance (Kampa et al., 2004; Jaganathan and Mandal, 2009; Feng et al., 2010; Puangpraphant et al., 2011; Weng and Yen, 2012), in our study we were unable to identify a significant activity. These findings are probably associated with the interference of several molecules present in the extract, which may have inhibited the antineoplastic action of this constituent (Devlin, 1997).

We also evaluate $P$. barbatus influence on cytokine modulation and found that PBO at $100 \mu \mathrm{g} \cdot \mathrm{mL}^{-1}$ significantly inhibited IFN- $\gamma$ and IL-17A cytokines. In accordance with these results, Kapewangolo et al. (2013) evaluated the influence of ethyl acetate fraction of $P$. barbatus leaves on secretion inhibition of proinflammatory cytokines by PBMCs and verified that this extract significatively inhibited the secretion of IL-2, IL-6, IL-10, TNF and IL-17A at 25 and $50 \mu \mathrm{g} \cdot \mathrm{mL}^{-1}$. Matu and Van Staden (2003) performed an anti-inflammatory activity test of the aqueous, hexanic and methanolic extracts of $P$. barbatus leaves at $500 \mu \mathrm{g} . \mathrm{L}^{-1}$ in a COX-1 inhibition assay and found a percentage of methanolic extract inhibition ( $88 \pm 3.5 \%$ ) higher than the aqueous extract ( $7.0 \pm 1.5 \%)$.

Besides the observation that $P$. barbatus extracts have immunomodulatory activity evidenced in some studies, as mentioned, our findings also corroborate with Gamaro et al. (2011) work due to the presence of caffeic acid in both extracts. At their study, where the authors demonstrated the immunomodulatory activity of caffeic acid and rosmarinic acid through carrageenan-induced pleurisy model and tail-flick assay in rats, the caffeic acid presented the most pronounced anti-inflammatory effect compared to rosmarinic acid. Thus, these results reinforce that extracts of $P$. barbatus have an anti-inflammatory potential, especially when is detect the phenolic compounds.
After the identification of the main constituents and biological activities of $P$. barbatus aqueous and organic extracts here observed, we reinforce the importance of researches related of phenolic compounds biological activities in order to elucidate novel therapeutic approaches for a variety of diseases. Moreover, we encourage the identification of the possible mechanisms of action of these substances with important pharmacological effects and medical interest.

\section{Conclusion}

Due to the fact of its low toxicity in human healthy cells and exhibits a variety of biological activities, including bacteriostatic, fungistatic and immunomodulatory activity, Plectranthus barbatus with phenolic compounds is a potential candidate for use as herbal medicine of medical interest.

\section{Acknowledgements}

The authors thank Dr. Rita de Cássia Pereira from the Herbarium of the Agricultural Research Institute (IPA, Recife, PE, Brasil) for plant species identification, and the Coordenação de Aperfeiçoamento de Pessoal de Nível Superior (CAPES) for financial support.

\section{References}

AGARWAL, K.C. and PARKS JUNIOR, R.E., 1983. Forskolin: a potential antimetastatic agent. International Journal of Cancer, vol. 32, no. 6, pp. 801-804. http://dx.doi.org/10.1002/ijc.2910320622. PMid:6686215.

AHMAD, A., KALEEM, M., AHMED, Z. and SHAFIQ, H., 2015. Therapeutic potential of flavonoids and their mechanism of action against microbial and viral Infections-a review. Food Research International, vol. 77, pp. 221-235. http://dx.doi. org/10.1016/j.foodres.2015.06.021.

ALASBAHI, R.H. and MELZIG, M.F., 2010. Plectranthus barbatus: a review of phytochemistry, ethnobotanical uses and pharmacology - Part 1. Planta Medica, vol. 76, no. 7, pp. 653-661. http://dx.doi.org/10.1055/s-0029-1240898. PMid:20178070.

ALDULAIMI, O.A., 2017. General overview of phenolics from plant to laboratory, good antibacterials or Not. Pharmacognosy Reviews, vol. 11, no. 22, pp. 123-127. http://dx.doi.org/10.4103/phrev. phrev_43_16. PMid:28989246.

ALMEIDA, A.A.P., 2007. Atividade antimicrobiana de extratos e de compostos fenólicos nitrogenados de café: avaliação in vitro e em modelo alimentar. Belo Horizonte: Faculdade de Farmácia, Universidade Federal de Minas Gerais, 137 p. Tese de Doutorado em Ciência de Alimentos.

ARAÚJO, S.G., ALVES, L.F., PINTO, M.E., OLIVEIRA, G.T., SIQUEIRA, E.P., RIBEIRO, R.I., FERREIRA, J.M. and LIMA, L.A., 2014. Volatile compounds of Lamiaceae exhibit a synergistic antibacterial activity with streptomycin. Brazilian Journal of Microbiology, vol. 45, no. 4, pp. 1341-1347. http://dx.doi.org/10.1590/S151783822014000400026. PMid:25763039.

ARAÚJO, S.G., LIMA, W.G., PINTO, M.E.A., MORAIS, M.I., DE SÁ, N.P., JOHANN, S., ROSA, C.A. and LIMA, L.A.R.S., 2019. Pharmacological prospection in-vitro of Lamiaceae species against human 
pathogenic fungi associated to invasive infections. Biocatalysis and Agricultural Biotechnology, vol. 21, pp. 101345. https://doi. org/10.1016/j.bcab.2019.101345.

ASSIS, F.V., SIQUEIRA, F.L., GONÇALVES, I.E., LACERDA, R.P., NASCIMENTO, R.A., ARAÚJO, S.G., ANDRADE, J.T., HERRERA, K.M.S., LIMA, L.A.R.S. and FERREIRA, J.M.S., 2018. Antibacterial activity of Lamiaceae plant extracts in clinical isolates of multidrug-resistant bacteria. Anais da Academia Brasileira de Ciências, vol. 90, no. 2, pp. 1665-1670. http://dx.doi. org/10.1590/0001-3765201820160870. PMid:29668795.

BORGES, A. S., MINOZZO, B. R., SANTOS, H., ARDISSON, J.S., RODRIGUES, R.P., ROMÃO, W., BORGES, W.S., GONÇALVES, R.C.R., BELTRAME, F.R. and KITAGAWA, R. R. (2020). Plectranthus barbatus Andrews as anti-Helicobacter pylori agent with activity against adenocarcinoma gastric cells. Industrial Crops \& Products vol. 146, pp; 1-12. https://doi.org/10.1016/j.indcrop.2020.112207.

BRITO, E., GOMES, E., FALÉ, P.L., BORGES, C., PACHECO, R., TEIXEIRA, V., MACHUQUEIRO, M., ASCENSÃO, L. and SERRALHEIRO, M.L.M., 2018. Bioactivities of decoctions from Plectranthus species related to their traditional use on the treatment of digestive problems and alcohol intoxication. Journal of Ethnopharmacology, vol. 220, pp. 147-154. http://dx.doi.org/10.1016/j.jep.2018.04.006. PMid:29626671.

CARDOSO, G.H.S., DANTAS, E.B.S., SOUSA, F.R.C. and PERON, A.P., 2014. Cytotoxicity of aqueous extracts of Rosmarinus officinalis L. (Labiatae) in plant test system. Brazilian Journal of Biology = Revista Brasileira de Biologia, vol. 74, no. 4, pp. 886-889. http:// dx.doi.org/10.1590/1519-6984.07313. PMid:25627599.

CARVALHO, L.V.N., CORDEIRO, M.F., E LINS, T.U.L., SAMPAIO, M.C.P.D., DE MELLO, G.S.V., DA COSTA, V.C.M., MARQUES, L.L.M., KLEIN, T., DE MELLO, J.C.P., CAVALCANTI, I.M.F., PITTA, I.R., GALDINO DA ROCHA PITTA, M. and RÊGO, M.J.B.M., 2016. Evaluation of antibacterial, antineoplastic, and immunomodulatory activity of Paullinia cupana Seeds crude extract and ethyl-acetate fraction. Evidence-Based Complementary and Alternative Medicine, vol. 2016, pp. 1-7. http://dx.doi.org/10.1155/2016/1203274. PMid:28053639.

CLINICAL AND LABORATORY STANDARDS INSTITUTE - CLSI, 2008. CLSI document M27A3. Reference method for broth dilution antifungal susceptibility testing of yeast: approved standard third edition. USA: CLSI.

CLINICAL AND LABORATORY STANDARDS INSTITUTE - CLSI, 2016. Unusual suspects - resistance concerns and susceptibility testing among less common, but Noteworthy BacteriaTech.Rep. USA: CLSI.

DEVLIN, J.P., 1997. High throughput screening: the discovery of bioactive substances. Marcel Dekker. 704 p. http://dx.doi. org/10.1201/9781482269802.

EZEONWUMELU, J.O.C., KAWOOYA, G.N., OKORUWA, A.G., DARE, S.S., EBOSIE, J.C., AKUNNE, A.A., TANAYEN, J.K. and UDECHUKWU, B.E., 2019. Phytochemical screening, toxicity, analgesic and antipyretic studies of aqueous leaf extract of Plectranthus barbatus [Andrews. Engl.] in rats. Pharmacology \& Pharmacy, vol. 10, no. 4, pp. 205-221. http://dx.doi.org/10.4236/pp.2019.104018.

FALÉ, P.L., MADEIRA, P.J., FLORÊNCIO, M.H., ASCENSÃO, L. and SERRALHEIRO, M.L., 2011. Function of Plectranthus barbatus herbal tea as neuronal acetylcholinesterase inhibitor. Food E Function, vol. 2, no. 2, pp. 130-136. http://dx.doi. org/10.1039/COFO00070A. PMid:21779558.

FENG, L., JIA, X., JIANG, J., ZHU, M., CHEN, Y., TAN, X.-B. and SHI, F., 2010. Combination of Active Components Enhances the Efficacy of Prunella in Prevention and Treatment of Lung Cancer. Molecules (Basel, Switzerland), vol. 15, no. 11, pp. 7893-7906. http://dx.doi.org/10.3390/molecules15117893. PMid:21060297.
GAMARO, G.D., SUYENAGA, E., BORSOI, M., LERMEN, J., PEREIRA, P. and ARDENGHI, P., 2011. Effect of rosmarinic and caffeic acids on inflammatory and nociception process in rats. International Scholarly Research Network ISRN Pharmacology, vol. 2011, pp. 1-6. http://dx.doi.org/10.5402/2011/451682. PMid:22084714.

GANASH, M. and QANASH, S., 2018. Phenolic acids and biological activities of Coleus forskohlii and Plectranthus barbatus as traditional medicinal plants. International Journal of Pharmacology, vol. 14, no. 6, pp. 856-865. http://dx.doi. org/10.3923/ijp.2018.856.865.

GENG, S., SUN, B., LU, R. and WANG, J., 2014. Coleusin factor, a novel anticancer diterpenoid, inhibits osteosarcoma growth by inducing bone morphogenetic protein-2-dependent differentiation. Molecular Cancer Therapeutics, vol. 13, no. 6, pp. 1431-1441. http://dx.doi.org/10.1158/1535-7163.MCT-130934. PMid:24723453.

GRAYER, R.J., ECKERT, M.R., VEITCH, N.C., KITE, G.C., MARIN, P.D., KOKUBUN, T., SIMMONDS, M.S. and PATON, A.J., 2003. The chemotaxonomic significance of two bioactive caffeic acid esters, nepetoidins A and B, in the Lamiaceae. Phytochemistry, vol. 64, no. 2, pp. 519-528. http://dx.doi.org/10.1016/S00319422(03)00192-4. PMid:12943769.

ICHIKAWA, T., DATE, M., ISHIKURA, T. and OZAKI, A., 1971. Improvement of Kasugamycin - producing strain by the agar piece method and the prototroph method. Folia Microbiologica, vol. 16, no. 3, pp. 218-224. http://dx.doi.org/10.1007/BF02884210. PMid:4935426.

JAGANATHAN, S.K. and MANDAL, M., 2009. Antiproliferative Effects of Honey and of Its Polyphenols: A Review. Journal of Biomedicine E Biotechnology, vol. 2009, pp. 1-13. http://dx.doi. org/10.1155/2009/830616. PMid:19636435.

KAMPA, M., ALEXAKI, V.I., NOTAS, G., NIFLI, A.P., NISTIKAKI, A., HATZOGLOU, A., BAKOGEORGOU, E., KOUIMTZOGLOU, E., BLEKAS, G., BOSKOU, D., GRAVANIS, A. and CASTANAS, E., 2004. Antiproliferative and apoptotic effects of selective phenolic acids on T47D human breast cancer cells: potential mechanisms of action. Breast Cancer Research, vol. 6, no. 2, pp. 63-74. http:// dx.doi.org/10.1186/bcr752. PMid:14979919.

KAPEWANGOLO, P., HUSSEIN, A.A. and MEYER, D., 2013. Inhibition of HIV-1 enzymes, antioxidant and anti-inflammatory activities of Plectranthus barbatus. Journal of Ethnopharmacology, vol. 149, no. 1, pp. 184-190. http://dx.doi.org/10.1016/j.jep.2013.06.019. PMid:23811046.

KĘPA, M., MIKLASIŃSKA-MAJDANIK, M., WOJTYCZKA, R.D., IDZIK, D., KORZENIOWSKI, K., SMOLEŃ-DZIRBA, J. and WĄSIK, T.J., 2018. Antimicrobial potential of caffeic acid against Staphylococcus aureus clinical strains. BioMed Research International, vol. 2018, pp. 1-8. http://dx.doi. org/10.1155/2018/7413504. PMid:30105241.

LORENZI, H. and MATOS, F.J.A., 2002. Plantas medicinais no Brasil: nativas e exóticas cultivadas. Nova Odessa: Instituto Plantarum. $206 \mathrm{p}$.

LUÍS, Â., SILVA, F., SOUSA, S., DUARTE, A.P. and DOMINGUES, F., 2013. Antistaphylococcal and biofilm inhibitory activities of gallic, caffeic, and chlorogenic acids. Biofouling, vol. 30, no. 1, pp. 69-79. http://dx.doi.org/10.1080/08927014.2013.845878 PMid:24228999.

LUKHOBA, C.W., SIMMONDS, M.S. and PATON, A.J., 2006. Plectranthus: a review of ethnobotanical uses. Journal of Ethnopharmacology, vol. 103, no. 1, pp. 1-24. http://dx.doi. org/10.1016/j.jep.2005.09.011. PMid:16289602.

MATU, E.N. and VAN STADEN, J., 2003. Antibacterial and antiinflammatory activities of some plants used for medicinal 
purposes in Kenya. Journal of Ethnopharmacology, vol. 87, no. 1, pp. 35-41. http://dx.doi.org/10.1016/S0378-8741(03)00107-7. PMid:12787952.

MIKLASI'NSKA-MAJDANIK, M.K., KĘPA, M., WOJTYCZKA, R.D., IDZIK, D., and WĄSIK, T.J., 2018. Phenolic compounds diminish antibiotic resistance of Staphylococcus Aureus clinical strains. International Journal of Environmental Research and Public Health, vol. 15, no. 10, pp. 2321. https://doi.org/10.3390/ijerph15102321. PMID: 30360435.

MOTHANA, R., AL-SAID, M., AL-MUSAYEIB, N., GAMAL, A., ALMASSARANI, S., AL-REHAILY, A., ABDULKADER, M. and MAES, L., 2014. In vitro antiprotozoal activity of abietane diterpenoids isolated from Plectranthus barbatus. International Journal of Molecular Sciences, vol. 15, no. 5, pp. 8360-8371. http://dx.doi. org/10.3390/ijms15058360. PMid:24823881.

PUANGPRAPHANT, S., BERHOW, M.A., VERMILLION, K., POTTS, G. and GONZALEZ DE MEJIA, E., 2011. Dicaffeoylquinic acids in Yerba mate (Ilex paraguariensis St. Hilaire) inhibit NF-kB nucleus translocation in macrophages and induce apoptosis by activating caspases-8 and-3 in human colon cancer cells. Molecular Nutrition E'Food Research, vol. 55, no. 10, pp. 1509-1522. http:// dx.doi.org/10.1002/mnfr.201100128. PMid:21656672.

RAUDONE, L., ZYMONE, K., RAUDONIS, R., VAINORIENE, R., MOTIEKAITYTE, V. and JANULIS, V., 2017. Phenological changes in triterpenic and phenolic composition of Thymus L. Species. Industrial Crops and Products, vol. 109, pp. 445-451. http:// dx.doi.org/10.1016/j.indcrop.2017.08.054.

RÊGO, M.J.B.D.M., GALDINO-PITTA, M.R., PEREIRA, D.T.M., DA SILVA, J.C., RABELLO, M.M., ALVES DE LIMA, M.C., HERNANDES, M.Z., DA ROCHA PITTA, I., GALDINO, S.L. and DA ROCHA PITTA, M.G., 2014. Synthesis, in vitro anticancer activity and in silico study of new disubstituted thiazolidinedione derivatives. Medicinal Chemistry Research, vol. 23, no. 6, pp. 3220-3226. http://dx.doi. org/10.1007/s00044-013-0902-z.

RICE, L.J., BRITS, G.J., POTGIETER, C.J. and VAN STADEN, J., 2011. Plectranthus: a plant for the future? South African Journal of Botany, vol. 77, no. 4, pp. 947-959. http://dx.doi.org/10.1016/j. sajb.2011.07.001.

RODRIGUES, T. S., GUIMARÃES, S.F., BRAGA, T.V., BASTOS, J.C.S.A. and RODRIGUES-DAS-DÔRES, R.G., 2016. Determination of content of phenolic compounds and flavonoids in leaves extracts of Plectranthus sp. ("Boldos"), potential antioxidant and antibacterial action. Academia Journal of Medicinal Plants, vol. 4, no. 10, pp. 062-068. https://doi.org/10.15413/ajmp.2016.0111.

RUNYORO, D.K.B., MATEE, M.I.N., NGASSAPA, O.D., JOSEPH, C.C. and MBWAMBO, Z.H., 2006. Screening of Tanzanian medicinal plants for anti-Candida activity. BMC Complementary and Alternative Medicine, vol. 6, no. 11, pp. 1-10. https://doi.org/10.1186/14726882-6-11. PMID: 16571139.

SAEED, M.E.M., MEYER, M., HUSSEIN, A. and EFFERTH, T., 2016. Cytotoxicity of South-African medicinal plants towards sensitive and multidrug-resistant cancer cells. Journal of Ethnopharmacology, vol. 186, pp. 209-223. http://dx.doi. org/10.1016/j.jep.2016.04.005. PMid:27058630.

SANTOS VERÍSSIMO, R., LINS, T., ASSIS BASTOS, M., ALBUQUERQUE SARMENTO, P., ALVINO, V., SILVA ARAUJO, M., LOPES SILVA, A. and ARAÚJO-JÚNIOR, J.2014. Antimicrobial activity of Plectranthus barbatus (Lamiacea). BMC Proceedings, vol. 8, suppl. 4, pp. 264. http://dx.doi.org/10.1186/1753-6561-8-S4-P264.

SHAHEEN, U., KHALIK, K.A., ABDELHADY, M.I.S., HOWLADAR, S., ALARJAH, M. and ABOUREHAB, M.A.S., 2017. HPLC Profile of Phenolic Constituents, Essential Oil Analysis and Antioxidant Activity of Six Plectranthus Species Growing in Saudi Arabia. Journal of Chemical and Pharmaceutical Research, vol. 9, no. 4, pp. 345-354.

SHERF, A.F., 1943. A method for maintaining Phytomonas sepedonica in culture for long periods without transfer. Phytopathology, vol. 33, pp. 330-332.

SILVA, C.F.G., MENDES, M.P., ALMEIDA, V.V., MICHELS, R.N., SAKANAKA, L.S. and TONIN, L.T.D., 2016. Parâmetros de qualidade físico-químicos e avaliação da atividade antioxidante de folhas de Plectranthus barbatus Andr. (Lamiaceae) submetidas a diferentes processos de secagem. Revista Brasileira de Plantas Medicinais, vol. 18, no. 1, pp. 48-56. http://dx.doi.org/10.1590/1983-084X/15_021.

SILVA, F.R.G., MATIAS, T.M.S., SOUZA, LI.O., MATOS-ROCHA, T.J., FONSECA, S.A., MOUSINHO, K.C. and SANTOS, A.F., 2019. Phytochemical screening and in vitro antibacterial, antifungal, antioxidant and antitumor activities of the red propolis Alagoas. Brazilian Journal of Biology = Revista Brasileira de Biologia, vol. 79, no. 3, pp. 452-459. http://dx.doi.org/10.1590/1519-6984.182959. PMid:30379200.

WENG, C.J. and YEN, G., 2012. Chemopreventive effects of dietary phytochemicals against cancer invasion and metastasis: phenolic acids, monophenol, polyphenol, and their derivatives. Cancer Treatment Reviews, vol. 38, no. 1, pp. 76-87. http://dx.doi. org/10.1016/j.ctrv.2011.03.001. PMid:21481535. 
Cordeiro, M.F. et al.

\section{Supplementary Material}

Supplementary material accompanies this paper.

Table S1. Mobile phase chromogenic agents and standards used to phytochemical characterization of Plectranthus barbatus extracts. Figure S1. Thin Layer Chromatography (TLC) analysis. Cinnamic derivatives (A); condensed tannins (B) hydrolysable tannins (C) terpenes/steroids (D).

This material is available as part of the online article from http://www.scielo.br/bjb 